\title{
A TEM study and non-isothermal crystallization kinetic of tellurite glass-ceramics
}

\author{
El Sayed Yousef • A. E. Al-salami • E. R. Shaaban
}

Received: 22 February 2010/Accepted: 28 May 2010/Published online: 15 June 2010

(c) The Author(s) 2010. This article is published with open access at Springerlink.com

\begin{abstract}
The glass transition temperature was studied via differential thermal analysis of glasses in the system $(100-x)$ $\mathrm{TeO}_{2}-5 \mathrm{Bi}_{2} \mathrm{O}_{3}-x \mathrm{ZnO}$ and $(100-x) \mathrm{TeO}_{2}-10 \mathrm{Bi}_{2} \mathrm{O}_{3}-x \mathrm{ZnO}$ where $x=15,20,25 \mathrm{in}$ mol\%. The crystallization behavior and microstructure development of the $0.7 \mathrm{TeO}_{2} / 0.1 \mathrm{Bi}_{2} \mathrm{O}_{3} /$ $0.2 \mathrm{ZnO}$ glass during annealing were investigated by nonisothermal differential thermal analysis (DTA), X-ray diffractometry, and transmission electron microscopy. The glass transition temperature, crystallization temperature, and the nature of crystalline phases formed were determined. From the heating rate dependence of the glass transition temperature, the glass transition activation energy was derived. From variation of DTA peak maximum temperature with heating rate, the activation energies of crystallization were calculated to be 305.8 and $197 \mathrm{~kJ} \mathrm{~mol}^{-1}$ for first and second crystallization exotherms, respectively. Moreover, synthesized crystalline $\mathrm{Bi}_{3.2} \mathrm{Te}_{0.8} \mathrm{O}_{6.4}, \mathrm{Bi}_{2} \mathrm{Te}_{4} \mathrm{O}_{11}$, and $\mathrm{Zn}_{2} \mathrm{Te}_{3} \mathrm{O}_{8}$ were investigated. In addition, the change in particle size with increasing annealing time was observed by high-polarized optical microscope.
\end{abstract}

E. S. Yousef $(\varangle) \cdot$ E. R. Shaaban

Physics Department, Faculty of Science, Al-Azhar University, Assuit 71542, Egypt

e-mail: omn_yousef2000@yahoo.com

A. E. Al-salami

Physics Department, Faculty of Science, King Khalid University, P.O. Box 9003, Abha, Saudi Arabia

Present Address:

E. S. Yousef

Physics Department, Faculty of Science, King Khalid University,

P.O. Box 9003, Abha, Saudi Arabia

\section{Introduction}

Nano-materials are considered as key technologies for this century. During the last 15 years, $\mathrm{TeO}_{2}$-based glasses have attracted much attention due to their linear and nonlinear refractive indices, excellent infrared transmittance. On the basis that, tellurium has an electronegativity in the range of other good glass forming oxide cations ( $\mathrm{Si}, \mathrm{B}, \mathrm{P}, \mathrm{Ge}, \mathrm{As}$, and $\mathrm{Sb}$ ) [1-3]. Considerable interest has been generated by glass-ceramics that demonstrate optical second harmonic generation [4-6]. Kim et al. [7] proposed transparent $\mathrm{TeO}_{2^{-}}$ based glasses containing ferroelectrics crystals as a new type of nonlinear optical glass; he had been tried to fabrication transparent $\mathrm{TeO}_{2}-\mathrm{Li}_{2} \mathrm{O}-\mathrm{Nb}_{2} \mathrm{O}_{5}$ glasses containing ferroelectrics $\mathrm{LiNbO}_{3}$ crystals, always accompanied by another phase, which was considered to be a metastable pyrochlore-type compound. Kazuhide et al. [8] described a new cubic crystalline phase formed in $\mathrm{TeO}_{2}-\mathrm{K}_{2} \mathrm{O}-\mathrm{Nb}_{2} \mathrm{O}_{5}$ glasses and glass-ceramic consisting of the phase that exhibits good optical at the wavelength of visible light. Komatsu et al. [9] obtained the crystalline phases in glassceramics of the $\mathrm{TeO}_{2}-\mathrm{Nb}_{2} \mathrm{O}_{5}-\mathrm{KTe}_{2} \mathrm{O}$ depend on the valence of $\mathrm{Te}$ ions in the glassy state. The valence of $\mathrm{Te}^{4+}$ is easily oxidized to $\mathrm{Te}^{6+}$ ions and it retained for heat treatments at temperatures $\leq 600{ }^{\circ} \mathrm{C}$ [1]. Tromel et al. [10] obtained cubic face centered non-stochiometric tellurites of lanthanides such as $\mathrm{Ln}_{2} \mathrm{Te}_{6} \mathrm{O}_{15}$ and $\mathrm{Ln}_{4} \mathrm{Te}_{7} \mathrm{O}_{15}$, in which Te ions are only $\mathrm{Te}^{4+}$, by quenching homogeneous liquids at room temperature (i.e., the valence of $\mathrm{Te}$ in $\mathrm{TeO}_{2}$-based glasses is $\mathrm{Te}^{4+}$ affects the crystallization). Sato et al. [11] obtained the crystalline phases in glass-ceramics of the $\mathrm{TeO}_{2}-\mathrm{RO}-\mathrm{Ln}_{2} \mathrm{O}_{3}$ where $\mathrm{R}=\mathrm{Mg}, \mathrm{Ba}, \mathrm{Zn}$, and $\mathrm{Ln}=\mathrm{Sm}$, $\mathrm{Eu}$, Er. Formed by laser irradiation are oriented at the surface. In our knowledge, few author have been fabricated $\mathrm{TeO}^{2-}$ based glasses to volume glass-ceramic because it is 
difficult to get transparent $\mathrm{TeO}^{2-}$ based glass-ceramic. Recently, Senthil Murugan et al. [12] found that the study of vitreous phases obtained in the $(100-2 x) \mathrm{TeO}_{2}-$ $x \mathrm{Bi}_{2} \mathrm{O}_{3}-x \mathrm{ZnO}$, where $x=5,10$, and 15 system resulted in nonlinear optical application. They found these glasses exhibit SHG, which is about one-order of magnitude higher than that obtained for the fused silica glass. The objective of our article is to determine the preparation of transparent glasses and transparent glass-ceramics with a new composition $70 \mathrm{TeO}_{2} / 10 \mathrm{Bi}_{2} \mathrm{O}_{3} / 20 \mathrm{ZnO}$, to characterize it by polarized optical microscope, TEM, DTA, and XRD, and finally to calculate the kinetic parameter, aiming to find the possible applications of this glass ceramics in optical devices.

\section{Theoretical background}

The theoretical basis for interpreting DTA results is provided by the formal theory of transformation kinetics as developed by Johnson and Mehl [13] and Avrami [14]. This theory describes the evolution with time, $t$, of the volume fraction crystallized, $\chi$, in terms of the crystal growth rate $u$;

$\chi=1-\exp \left[-g N_{0}\left(\int_{0}^{t} u\left(t^{\prime}\right) \mathrm{d} t^{\prime}\right)^{m}\right]$,

where $N_{0}$ is the number of pre-existing nuclei per unit volume, $n$ and $m$ are kinetic exponents, which depends on the dimensionality of the crystal growth. In the considered case, "site saturation" [15], the kinetic exponent is $n=m$. Assuming an Arrhenian temperature dependence for $u=u_{0} \mathrm{e}^{E / R T^{\prime}}$, and a heating rate, $\beta=\frac{\mathrm{d} T}{\mathrm{~d} t}$, Eq. 1 becomes:

$$
\begin{aligned}
\chi & =1-\exp \left[-g \cdot N_{0} \cdot u_{0}^{n} \cdot \beta^{-n}\left(\int_{T_{0}}^{T} \mathrm{e}^{-E / R T^{\prime}} \mathrm{d} T^{\prime}\right)^{n}\right] \\
& =1-\exp \left(-q I^{n}\right),
\end{aligned}
$$

where $E$ is the effective activation energy for crystal growth. By using the substitution $y^{\prime}=\frac{E}{R T^{\prime}}$, the integral, $I$, can be represented, according to the literature [16], by the sum of the alternating series:

$S^{\prime}\left(y^{\prime}\right)=\left(\frac{-\mathrm{e}^{-y \prime}}{y^{\prime 2}}\right) \cdot \sum_{k=0}^{\infty} \frac{(-1)^{k}(k+1)}{y^{\prime k}}$.

Considering that in this type of series the error produced is less than the first term neglected and bearing in mind that in most crystallization reactions $y^{\prime}=\frac{E}{R T} \gg 1$ [usually $\frac{E}{R T^{\prime}} \geq 25$ ], it is possible to use the first term of this series, without making any appreciable error, and the abovementioned integral becomes:
$I=\left(\frac{E}{R}\right) \cdot \mathrm{e}^{-y} \cdot y^{-2}=R \cdot T^{2} \cdot E^{-1} \cdot \exp \left(\frac{-E}{R T}\right)$

if $T_{0}=T$ (where $T_{0}$ is the starting temperature) so that $y_{0}$ is infinite. This assumption is justifiable for any thermal treatment that begins at a temperature where crystal growth is negligible, i.e., below the glass transition temperature, $T_{\mathrm{g}}$ [17].

Substituting Eq. 3 into Eq. 2, the volume fraction crystallized in a non-isothermal process is expressed as:

$\chi=1-\exp \left[-Q \cdot\left(K_{R} \cdot T^{2} \cdot \beta^{-1}\right)^{n}\right]$

where $Q=g \cdot N_{0} \cdot\left(\frac{R}{E}\right)^{n}$, a general expression for all values of the parameter $n$, which, as it is well known, in the case of "site saturation" depends on the mechanism of the crystal growth.

With the aim of calculating the kinetic parameters, the crystallization rate has been obtained by deriving Eq. 4 with respect to time, yielding:

$$
\begin{aligned}
\frac{\mathrm{d} x}{\mathrm{~d} t}= & n \cdot Q \cdot\left[k_{R} \cdot T^{2} \cdot \beta^{-1}\right]^{n-1} \cdot(1-x) \\
& \cdot\left[k_{R} \cdot E \cdot R^{-1}+2 k_{R} \cdot T\right],
\end{aligned}
$$

which has been assumed that the reaction rate constant is a time function through its Arrhenian temperature dependence. The maximum crystallization rate is found by making $\frac{\mathrm{d}^{2} x}{\mathrm{~d} t^{2}}=0$, thus the relationship:

$$
\left[\left(\frac{K_{R} \cdot \beta}{T_{P}^{2}}\right)\right]^{n}=1-\left(\frac{2}{n}\right) \cdot\left(1+\frac{E}{R T_{P}}\right) \cdot\left(2+\frac{E}{R T_{P}}\right)^{-2}
$$

where the subscript, $P$, denotes the magnitude values corresponding to the maximum crystallization rate. Assuming the above-mentioned hypothesis $\frac{E}{R T_{P}} \gg 1$; the logarithmic form of Eq. 7 is written as:

$\ln \left(\frac{T_{P}^{2}}{\beta}\right)=\frac{E}{R T_{P}}-\ln q=0$

which is the equation of a straight line, whose slope and intercept give the activation energy, $E$, and the pre-exponential factor, $q=Q^{\frac{1}{n}} \cdot K_{R}$, respectively.

On the other hand, the quoted assumption, $\frac{E}{R T_{P}} \gg 1$, according to Eq. 4-6, allows us to express the maximum crystallization rate by the relationship:

$\left.\frac{\mathrm{d} x}{\mathrm{~d} t}\right|_{p}=0.37 \beta \cdot E \cdot n \cdot\left(R T_{P}^{2}\right)^{-1}$

which makes it possible to obtain for each heating rate a value of the kinetic exponent, $n$. The corresponding mean value may be taken as the most probable value of the quoted exponent. 


\section{Experimental work}

Glasses in the system $(100-x) \mathrm{TeO}_{2}-5 \mathrm{Bi}_{2} \mathrm{O}_{3}-x \mathrm{ZnO}$ and $(100-x) \mathrm{TeO}_{2}-10 \mathrm{Bi}_{2} \mathrm{O}_{3}-x \mathrm{ZnO}$ where $x=15,20,25 \mathrm{in}$ mol\% were prepared by mixing specified weights of raw material. Mixed batches were melted in gold crucible at $850{ }^{\circ} \mathrm{C}$ for $\sim 30 \mathrm{~min}$. The melt, which had a high viscosity, was cast at $700{ }^{\circ} \mathrm{C}$ in a graphite mold. Subsequently, the sample was transferred to an annealing furnace and kept for $2 \mathrm{~h}$ at $300{ }^{\circ} \mathrm{C}$. Then, the furnace was switched off and the glass sample was allowed to cool. Samples for measurements of optical properties using DTA (Shimadzu DTA 50) curve of powdered specimen of about $30 \mathrm{mg}$ were recorded in air at heating rate 3,5 , and $10 \mathrm{~K} \mathrm{~min}^{-1}$, respectively, in Pt-crucible and using the same amount of $\mathrm{Al}_{2} \mathrm{O}_{3}$ as reference material in the range between 20 and $650{ }^{\circ} \mathrm{C}$. The glass transition temperatures $\left(T_{\mathrm{g}}\right)$ is a selected as mid-point between the onset and the minimum temperature, where $T_{\mathrm{c}}$ is measured at the onset of crystallization, the $T_{\mathrm{p}}$ is measured at the peak of crystallization.

$\mathrm{X}$-ray diffraction (XRD) investigation were carried out in Siemens D 5000 using $\left(\mathrm{CuK}_{\alpha}\right.$ radiation) diffractometer at $40 \mathrm{kV}$ and $40 \mathrm{mV}$ setting in $2 \theta$ range from $10^{\circ}$ to $90^{\circ}$. The crystallized phases were identified by comparing the peak position and intensities with those in the JCPDS (Joint Committee on Powder Diffraction Standards) date files. The volume crystallized sample was studied by TEM (Hitachi H8100) using $200 \mathrm{kV}$ and optical sample was coated with carbon for TEM study. Optical microscopy $(\mathrm{OM})$ investigation were performed in Zeiss Optimas equipped with Nikon Coolpix 4.0 MP digital camera.

\section{Results and discussion}

Homogeneous and transparent glasses were prepared in the system $(100-x) \mathrm{TeO}_{2}-5 \mathrm{Bi}_{2} \mathrm{O}_{3}-x \mathrm{ZnO}$ and $(100-x)$ $\mathrm{TeO}_{2}-10 \mathrm{Bi}_{2} \mathrm{O}_{3}-x \mathrm{ZnO}$, where $x=15,20,25$ in mol\%. Differential thermal analysis (DTA) investigation was conducted on the as-cast prepared glasses. Figure 1 shows that, the glass transition temperature increase with increasing $\mathrm{ZnO}$ content, and also it increases with increasing $\mathrm{Bi}_{2} \mathrm{O}_{3}$ content in the glass matrix. $T_{\mathrm{g}}$ as a function of composition can reveal a transformation of the glass structure. We expect that, $\mathrm{ZnO}$ and $\mathrm{Bi}_{2} \mathrm{O}_{3}$ break down the $\mathrm{TeO}_{4}$ network structure creating $\mathrm{TeO}_{3+1}$ and $\mathrm{TeO}_{3}$ phase built in the glass matrix that results in the structural rearrangements of the glasses due to the transfer of the bridging oxygen into elongate bridging oxygen and nonbridging oxygen. The values of bond $\mathrm{Te}-\mathrm{O}$ have four different kinds; $\mathrm{Te}-\mathrm{NBO}_{\mathrm{ax}}, \mathrm{Te}-\mathrm{NBO}_{\mathrm{eq}}, \mathrm{Te}-\mathrm{BO}_{\mathrm{ax}}$, and $\mathrm{Te}-\mathrm{BO}_{\text {eq }}$, which is due to $\mathrm{NBO}$ with axial position, NBO with equatorial position, $\mathrm{BO}$ with axial position, and $\mathrm{BO}$

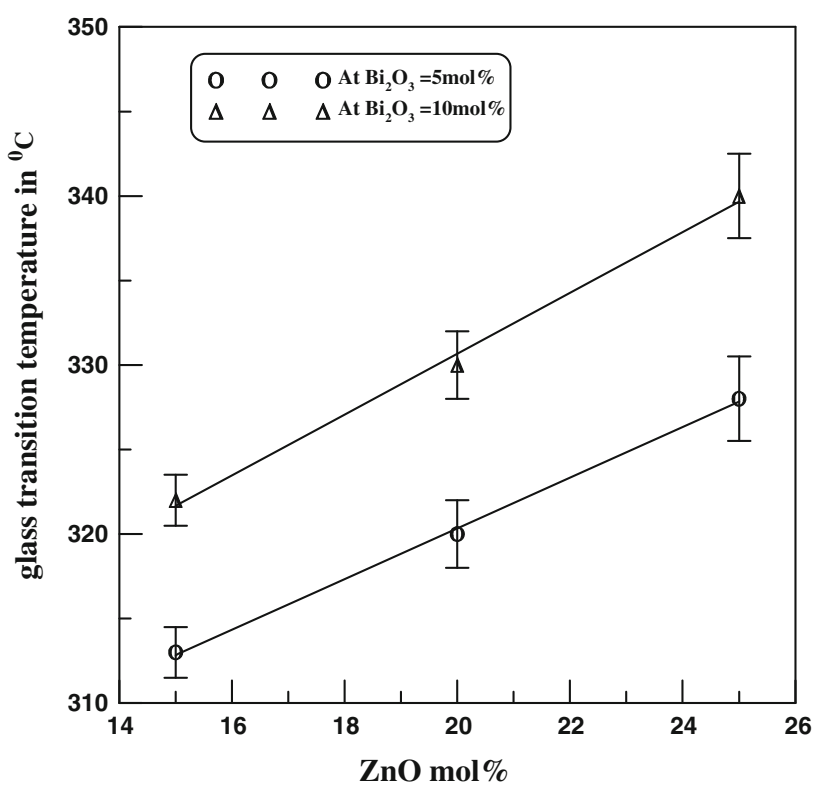

Fig. 1 The glass transition temperature with $\mathrm{ZnO}$ content in mol\% in the prepared glasses

with equatorial position. This explains why, the glass transition temperature increase with both increasing $\mathrm{ZnO}$ and $\mathrm{Bi}_{2} \mathrm{O}_{3}$ content in the network glass $\mathrm{TeO}_{2} / \mathrm{Bi}_{2} \mathrm{O}_{3} / \mathrm{ZnO}$. Figure 2a illustrates the respective DTA thermograms of as-cast $70 \mathrm{TeO}_{2}-10 \mathrm{Bi}_{2} \mathrm{O}_{3}-20 \mathrm{ZnO}$ glass sample scanned at heating rate of $10{ }^{\circ} \mathrm{C} / \mathrm{min}$. The glass transition $\left(T_{\mathrm{g}}\right)$, the two peaks crystallization temperature $\left(T_{\mathrm{p} 1}\right.$ and $\left.T_{\mathrm{p} 2}\right)$, and melting temperature $\left(T_{\mathrm{m}}\right)$ are marked on the thermograms. As seen in Fig. 1, DTA scan exhibits a small exothermic peak corresponding to the glass transition $\left(T_{\mathrm{g}}\right)$, and two exothermic peaks corresponds to the formation and/or transformation of crystalline phase. Onset crystallization temperature $\left(T_{\mathrm{c}}\right)$ and peak temperature of crystallization $\left(T_{\mathrm{P}}\right)$ is given in Table 1. Figure $1 \mathrm{~b}$ depicts the DTA traces for the first crystallized peak of $70 \mathrm{TeO}_{2} / 10 \mathrm{Bi}_{2} \mathrm{O}_{3} / 20 \mathrm{ZnO}$ at $\beta=10 \mathrm{~K} / \mathrm{min}$, besides the fraction, $\chi$ (crystallized at a given temperature $T$ ) given by $\chi=A_{\mathrm{T}} / A$, where $A$ is the total area of the exothermic peak between the temperatures, $T_{\mathrm{i}}$ (the onset of crystallization) and $T_{\mathrm{f}}$ (the full crystallization). $A_{\mathrm{T}}$ is the area between $T_{\mathrm{i}}$ and $T$. The graphical representation of the crystallized volume fraction shows the typical sigmoid curve as a function of temperature for different heating rates for the first crystallization curve $70 \mathrm{TeO}_{2} / 10 \mathrm{Bi}_{2} \mathrm{O}_{3} / 20 \mathrm{ZnO}$ (Fig. 2a, b) based on mentioned work elsewhere $[18,19]$. Figure 3 shows the plots $\ln \left(\frac{T_{g}^{2}}{\beta}\right)$ versus $\left(\frac{1}{T_{\mathrm{g}}}\right)$ for the glass powder displaying the linearity of the equations used. The values of the activation energy obtained for the glass transition are $460.7 \mathrm{~kJ} \mathrm{~mol}^{-1}$. The crystallization maximum temperature is observed to increase with the increase in heating rate (see Table 1). The crystallization maximum in DTA scans corresponds to the 
Table 1 The values of glass transition, $T_{\mathrm{g}}$, peak of crystallization, $T_{\mathrm{p}}$, maximum crystallization rate, and kinetic exponent for the different heating rates

\begin{tabular}{|c|c|c|c|c|c|c|c|c|c|}
\hline \multirow[t]{2}{*}{$\beta\left(\mathrm{K} \mathrm{min}^{-1}\right)$} & \multirow[t]{2}{*}{$T_{\mathrm{g}}(\mathrm{K})$} & \multicolumn{2}{|l|}{$T_{\mathrm{p}}(\mathrm{K})$} & \multicolumn{2}{|c|}{$(\mathrm{d} \gamma / \mathrm{d} t)$ in $10^{-3} \mathrm{~S}^{-1}$} & \multicolumn{2}{|c|}{ First peak } & \multicolumn{2}{|c|}{ Second peak } \\
\hline & & First peak & Second peak & First peak & Second peak & $n$ & $<n>$ & $n$ & $<n>$ \\
\hline 3 & 604 & 670 & 714 & 1.3726 & 1.1765 & 0.905 & 0.903 & 1.204 & 1.201 \\
\hline 5 & 607 & 674 & 723 & 2.2518 & 1.9301 & 0.903 & & 1.201 & \\
\hline 10 & 612 & 684 & 739 & 4.368 & 3.744 & 0.901 & & 1.199 & \\
\hline
\end{tabular}
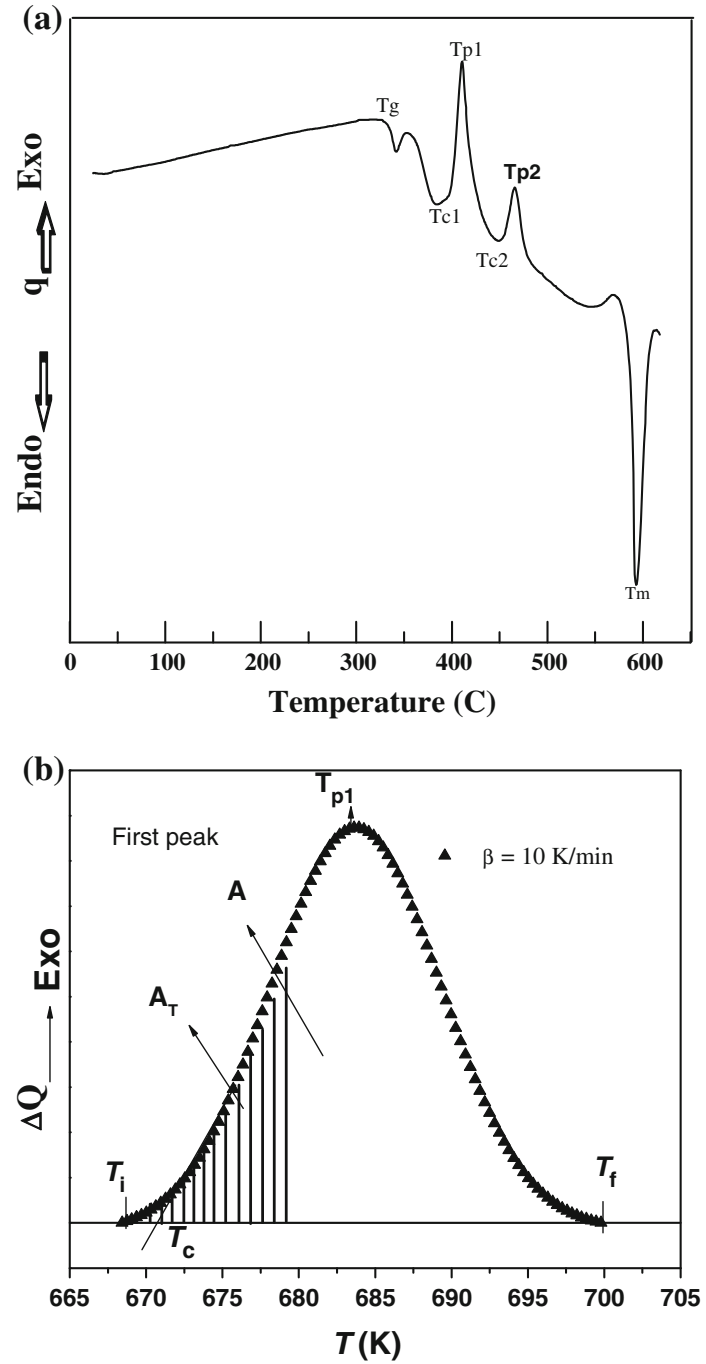

Fig. 2 Typical DTA traces of glass $70 \mathrm{TeO}_{2}-10 \mathrm{Bi}_{2} \mathrm{O}_{3}-20 \mathrm{ZnO}$ at $10 \mathrm{~K} \mathrm{~min}^{-1}$

temperature at which the rate of transformation of the viscous liquid into crystals becomes maximum. This means that, the number of nucleation site is increased by using slower heating rates and the peak maximum will occur at a temperature which the melt viscosity is higher at lower temperature.

The ratio between the ordinates of the DTA curve and the total area of the peak gives the corresponding
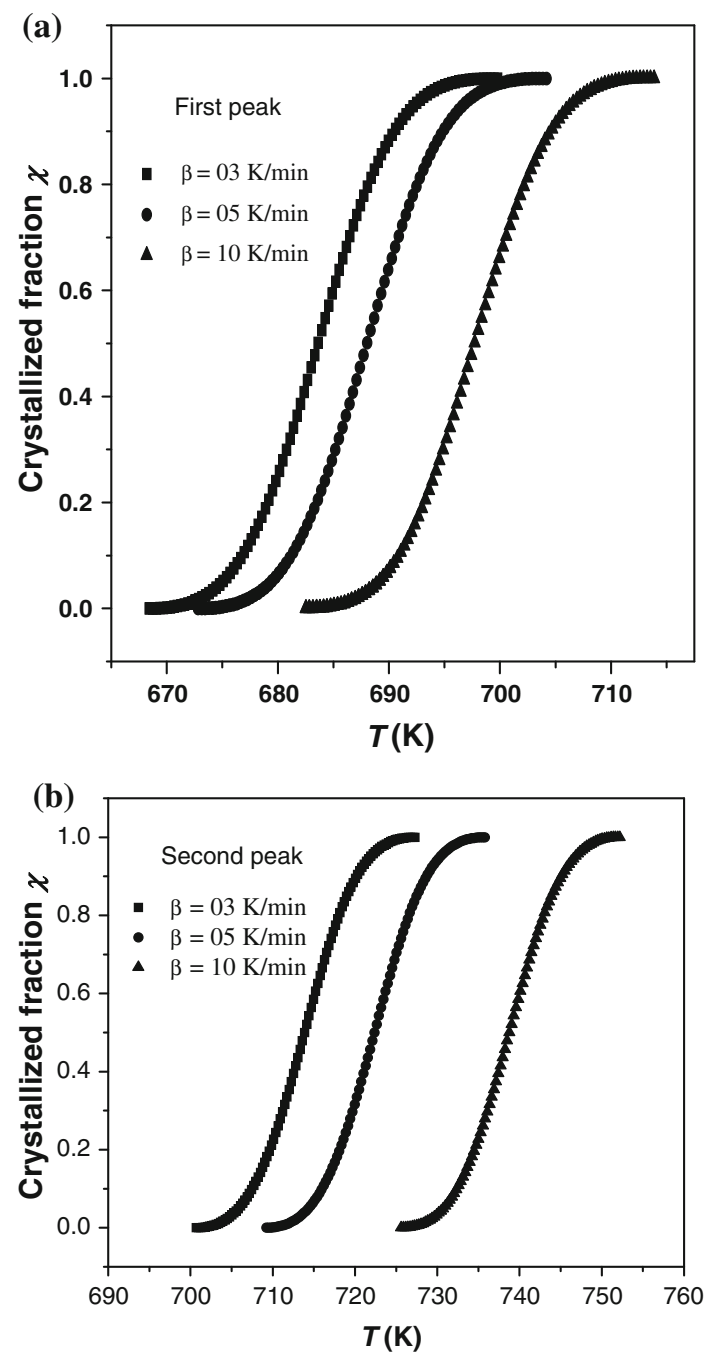

Fig. 3 a Crystallized friction as a function of temperature at different heating rates for first crystallization curve and $\mathbf{b}$ crystallized fraction as a function of temperature different heating rates for second crystallization curve

crystallization rates, which makes it possible to build the curves of the exothermal peaks depicted in Fig. 4a, b. It was observed that, the values of $(\mathrm{d} x / \mathrm{d} t)_{\mathrm{p}}$ increase with the increase in the heating rate. From the experimental values of the $(\mathrm{d} x / \mathrm{d} t)_{\mathrm{p}}$, one can calculate the kinetic exponent $n$ from Eq. 9. The value of kinetic exponent, $n$, for both the 


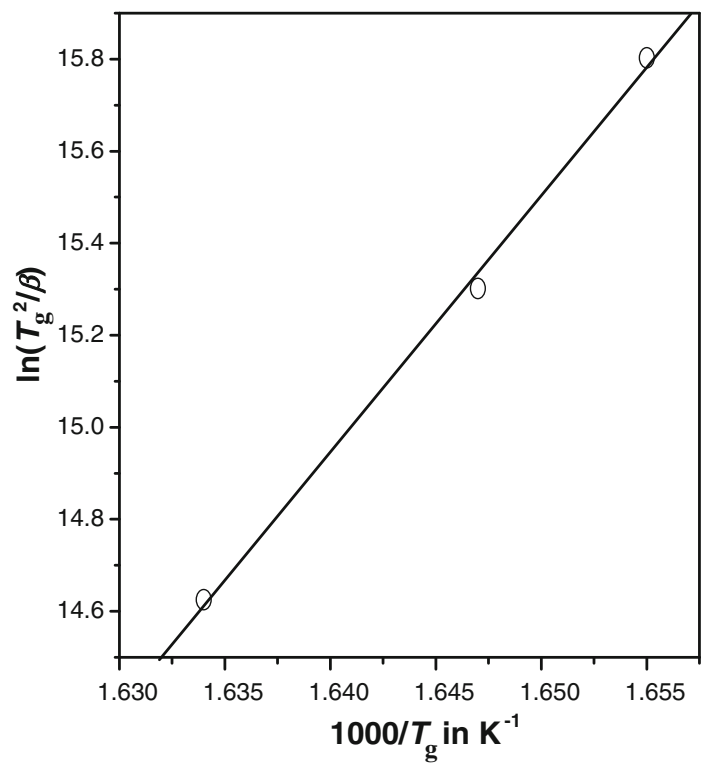

Fig. 4 Plots of $\ln \left(\frac{T_{\mathrm{g}}^{2}}{\beta}\right)$ versus $\frac{1000}{T_{p}}$ of studied glass $\left(\beta\right.$ in $\left.\mathrm{K} \min ^{-1}\right)$
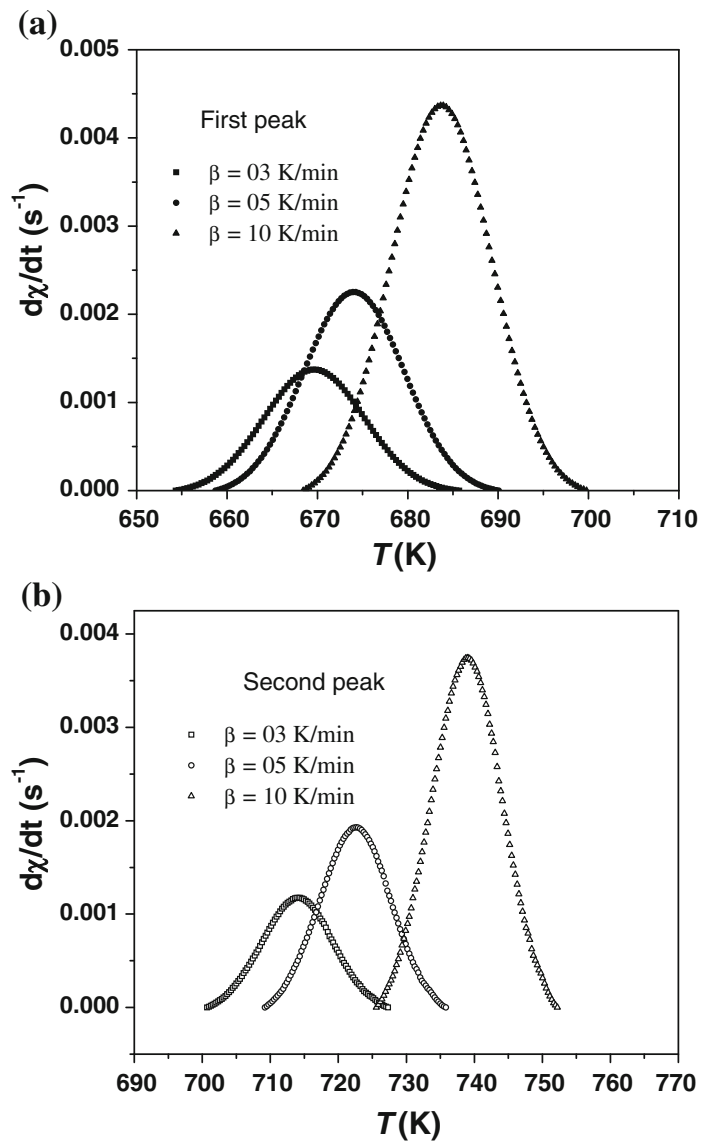

Fig. 5 a Crystallization rate versus temperature of the first exothermic peak at different heating rates and $\mathbf{b}$ crystallization of the second exothermic peak at different heating rates

phases at each of the experimental heating rates is given in Table 1 . The value of $n$ depends on the mechanism of the transformation reaction.
Table 2 The values of activation energy for glass transition and crystallization of $70 \mathrm{TeO}_{2}-20 \mathrm{ZnO}-10 \mathrm{Bi}_{2} \mathrm{O}_{3}$

\begin{tabular}{lll}
\hline Parameter & First peak & Second peak \\
\hline $\begin{array}{l}\text { Activation energy of } \\
\text { glass transition }\left(\mathrm{kJ} \mathrm{mol}^{-1}\right)\end{array}$ & 460.7 & \\
$\begin{array}{l}\text { Activation energy of } \\
\text { crystallization }\left(\mathrm{kJ} \mathrm{mol}^{-1}\right)\end{array}$ & 305.8 & 197 \\
\hline
\end{tabular}

Plot $\ln \left(\frac{T_{P}^{2}}{\beta}\right)$ versus $\left(\frac{1}{T_{P}}\right)$ for crystallization of the glass is shown in Fig. 5. A linear plot indicates the validity of Kissinger method [17]. The activation energy for crystallization of first phase is $305.8 \mathrm{~kJ} \mathrm{~mol}^{-1}$, and second phase is $197 \mathrm{~kJ} \mathrm{~mol}^{-1}$ (see Table 2).

In order to fabricate $70 \mathrm{TeO}_{2}-10 \mathrm{Bi}_{2} \mathrm{O}_{3}-20 \mathrm{ZnO}$ glassceramic, we applied heat treatment condition which led to the precipitation of crystalline phases. On the basis of DTA results, X-ray diffractometry scans were carried out to verify the nature of crystallizing phases in the glass network at temperature above $T_{\mathrm{g}}$ for prepared glasses. The XRD patterns for this sample at different heating temperature are shown in Figs. 6, 7. First, the $70 \mathrm{TeO}_{2}-10 \mathrm{Bi}_{2} \mathrm{O}_{3}-$ 20ZnO glass tempered at $350{ }^{\circ} \mathrm{C}$ for $3 \mathrm{~h}$ [see Fig. 6 (chart a)] and $350{ }^{\circ} \mathrm{C}$ for $4 \mathrm{~h}$ [see Fig. 6 (chart b)], it has one crystalline phase $\mathrm{Bi}_{3.2} \mathrm{Te}_{0.8} \mathrm{O}_{6.4}$ (ICDD card: 00-049-1761). The important $\mathrm{Bi}_{3.2} \mathrm{Te}_{0.8} \mathrm{O}_{6.4}$ was of the best solid-state oxygen ion conductors. Also, the X-ray diffractogram estimates that the same crystalline phase appears in our prepared glass tempered at $375{ }^{\circ} \mathrm{C}$ for $1.5 \mathrm{~h}$ [see Fig. 7 (chart a)]. When the prepared glass tempered at $375{ }^{\circ} \mathrm{C}$ for $3 \mathrm{~h}$, two phases $\mathrm{Bi}_{3.2} \mathrm{Te}_{0.8} \mathrm{O}_{6.4}$ and $\mathrm{Zn}_{2} \mathrm{Te}_{3} \mathrm{O}_{8}$ were obtained as shown in Fig. 7 (chart b), and three crystalline phases $\mathrm{Bi}_{3.2} \mathrm{Te}_{0.8} \mathrm{O}_{6.4}, \mathrm{Zn}_{2} \mathrm{Te}_{3} \mathrm{O}_{8}$ (ICDD card: 20-1270), $\mathrm{Bi}_{2} \mathrm{Te}_{4} \mathrm{O}_{11}$ (ICDD card: 01-081-1330), respectively, were obtained, when it tempered $375{ }^{\circ} \mathrm{C}$ for $4.5 \mathrm{~h}$ as shown in

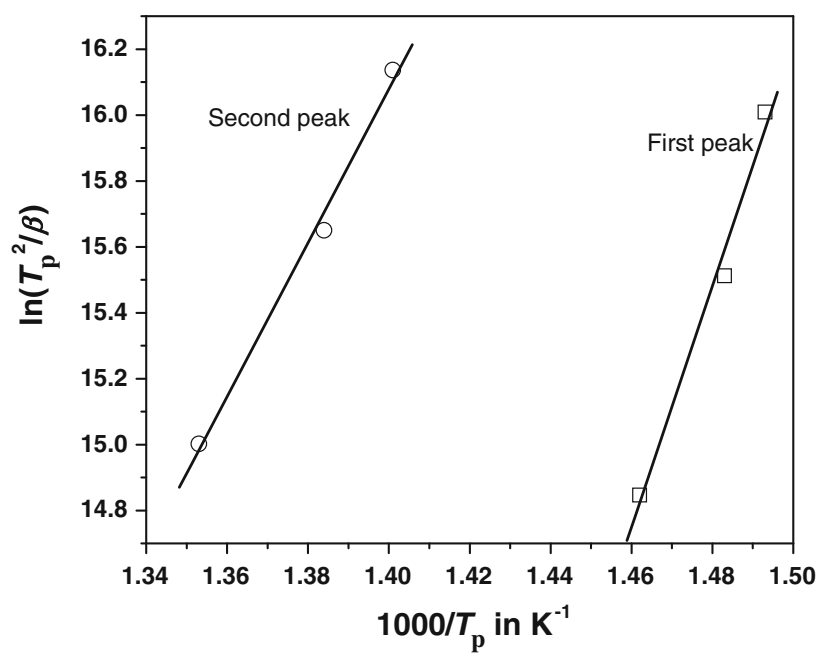

Fig. 6 Plots of $\ln \left(\frac{T_{p}^{2}}{\beta}\right)$ versus $\frac{1000}{T_{p}}$ of studied glass $\left(\beta\right.$ in $\left.\mathrm{K} \mathrm{min}^{-1}\right)$ 


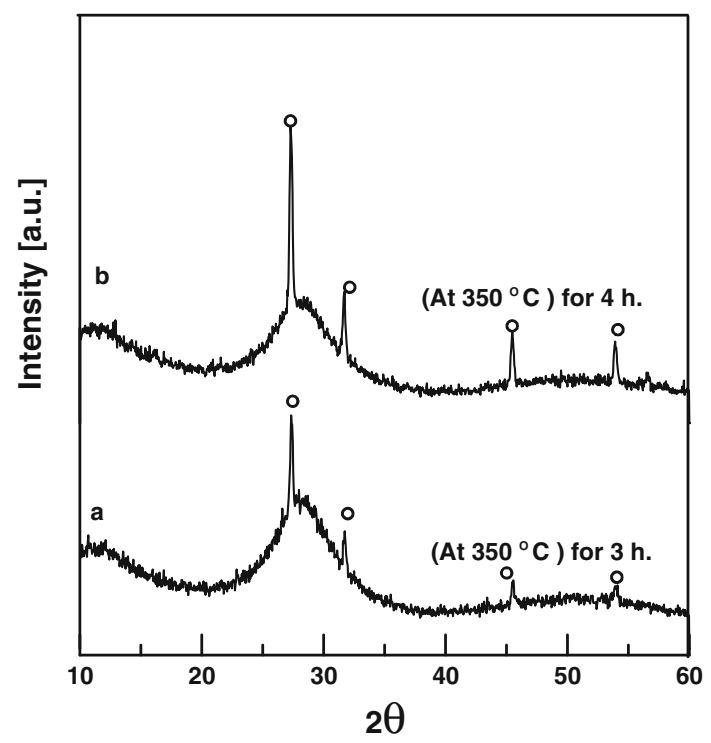

Fig. 7 XRD patterns of tempered sample $70 \mathrm{TeO}_{2}-10 \mathrm{Bi}_{2} \mathrm{O}_{3}-20 \mathrm{ZnO}$ (chart $a, 350{ }^{\circ} \mathrm{C} / 3 \mathrm{~h}$ ), (chart $b, 350{ }^{\circ} \mathrm{C} / 4 \mathrm{~h}$ ) (open circle) $\mathrm{Bi}_{3.2} \mathrm{Te}_{0.8} \mathrm{O}_{6.4}$

Fig. 8 (chart c). Furthermore, heat treatment at higher temperature leads to the complete reaction of $\mathrm{Bi}_{2} \mathrm{O}_{3}$ with $\mathrm{TeO}_{2}$ to form the stoichiometric compound $\mathrm{Bi}_{2} \mathrm{Te}_{4} \mathrm{O}_{11}$. Senthil Murugan et al. [12] estimated the primary phase $\mathrm{Bi}_{3.2} \mathrm{Te}_{0.8} \mathrm{O}_{6.4}$ which belongs to the cubic (centro symmetric) phase along with traces of $\mathrm{Bi}_{2} \mathrm{TeO}_{5}$ in the $70 \mathrm{TeO}_{2}-$ $15 \mathrm{Bi}_{2} \mathrm{O}_{3}-15 \mathrm{ZnO}$ glass heat treated at $350{ }^{\circ} \mathrm{C} / 6 \mathrm{~h}$. Also, they were found only major phase $\mathrm{Bi}_{2} \mathrm{Te}_{4} \mathrm{O}_{11}$ in the same sample heat treated at $500{ }^{\circ} \mathrm{C} / 6 \mathrm{~h}$. Kozhukharov et al. [20] estimated the phase of $\alpha-\mathrm{TeO}_{2}$ at the temperature $435{ }^{\circ} \mathrm{C}$ and $\mathrm{Te}_{3} \mathrm{Zn}_{2} \mathrm{O}_{8}$ at $479{ }^{\circ} \mathrm{C}$ for $80 \mathrm{~mol} \% \mathrm{TeO}_{2}$ and $20 \mathrm{~mol} \%$ $\mathrm{ZnO}$ composition and concluded the crystallizing $\mathrm{Zn}_{2} \mathrm{Te}_{3} \mathrm{O}_{8}$ phase only at $432{ }^{\circ}$ in the $60 \mathrm{~mol} \% \mathrm{TeO}_{2}$ and $40 \mathrm{~mol} \% \mathrm{ZnO}$, which corresponds to single crystallization peak. It is well known that in the $\mathrm{Zn}_{2} \mathrm{Te}_{3} \mathrm{O}_{8}$ structure ${ }_{\infty}^{1}\left[\mathrm{Te}(4) \mathrm{Te}_{2}(3+1) \mathrm{O}_{8}\right]$ chains are formed where for one $\mathrm{TeO}_{4}$ polyhedron, there are two $\mathrm{TeO}_{3}$ trigonal pyramids. Popple et al. [21] detected $\mathrm{Bi}_{2} \mathrm{Te}_{4} \mathrm{O}_{11}$ phase in the $\mathrm{Bi}_{2} \mathrm{O}_{3}-$ $\mathrm{TeO}_{2}$. Moreover, the $\mathrm{TeO}_{2}$ evaporates onto the $\mathrm{Bi}_{2} \mathrm{O}_{3}$ grains producing $\mathrm{TeO}_{2}$ layer, and hence this $\mathrm{TeO}_{2}$ layer reacts with the $\mathrm{Bi}_{2} \mathrm{O}_{3}$ by bulk diffusion forming $\mathrm{Bi}_{2} \mathrm{Te}_{4} \mathrm{O}_{11}$ reactions. From the previous reported data, we conclude that, $\mathrm{Bi}_{3.2} \mathrm{Te}_{0.8} \mathrm{O}_{6.4}, \mathrm{Zn}_{2} \mathrm{Te}_{3} \mathrm{O}_{8}$, and $\mathrm{Bi}_{2} \mathrm{Te}_{4} \mathrm{O}_{11}$ reactions also are taking place by bulk diffusion in our glasses, not new crystalline phases appeared in prepared glass. Furthermore the activation energy of obtained crystalline phases in the prepared glass are 305.8 and $197 \mathrm{~kJ} \mathrm{~mol}^{-1}$ and the kinetic parameter, $n$, for both crystallization exotherms closed to 1.0 (i.e., one dimensional growth from surface to inside).

The prepared glasses are high homogeneity transparent glass-ceramics depending on the heat treatment condition.

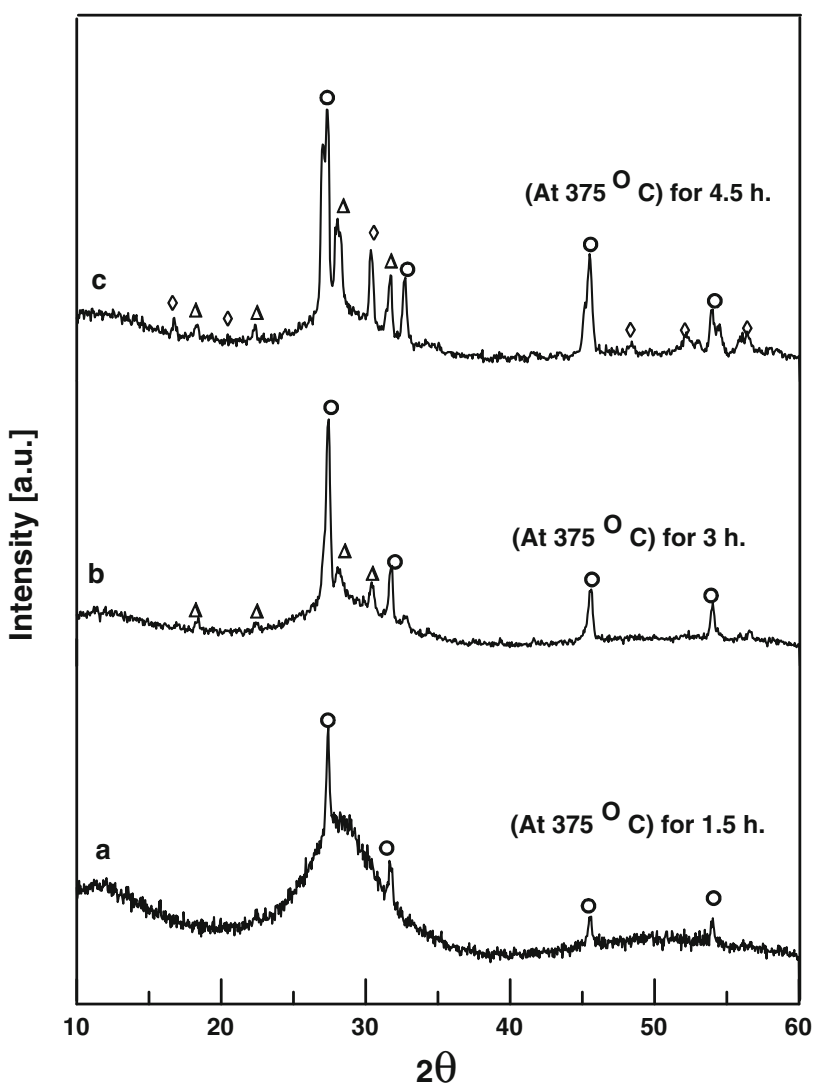

Fig. 8 XRD patterns of tempered sample $70 \mathrm{TeO}_{2}-10 \mathrm{Bi}_{2} \mathrm{O}_{3}-20 \mathrm{ZnO}$ (chart $\left.a, 375{ }^{\circ} \mathrm{C} / 1.5 \mathrm{~h}\right),\left(\operatorname{chart} b, 375{ }^{\circ} \mathrm{C} / 3 \mathrm{~h}\right)$, (chart $c, 375{ }^{\circ} \mathrm{C} / 4.5 \mathrm{~h}$ ), (open circle) $\mathrm{Bi}_{3.2} \mathrm{Te}_{0.8} \mathrm{O}_{6.4}$, (open triangle) $\mathrm{Zn}_{2} \mathrm{Te}_{3} \mathrm{O}_{8}$ and (open rhombus) $\mathrm{Bi}_{2} \mathrm{Te}_{4} \mathrm{O}_{11}$

Therefore, it is easy to take the photos of crossed polarized transmission microscope for the $70 \mathrm{TeO}_{2}-10 \mathrm{Bi}_{2} \mathrm{O}_{3}-20 \mathrm{ZnO}$ glass at different heating temperature are shown in Fig. 9a-e. It has high-nucleation density of crystallites when tempered at $350{ }^{\circ} \mathrm{C}$ at different times $1,2,3$, and $4 \mathrm{~h}$. (see Fig 9a-e). Also, the grain size of crystallites increases with increasing the time of sample thermally treated. The prepared sample was examined under transmission electron microscope (TEM) after sputtering a thin carbon film on the prepared glass for conduction. The TEM micrographs for this sample were shown in Fig. 10a-d, which indicate that the scattered crystallites are uniform size in range $5 \mu \mathrm{m}$ in the prepared sample tempered at $350{ }^{\circ} \mathrm{C} / 4 \mathrm{~h}$. Also, Fig. 10a revealed centrosymmetric tridymite crystal in the matrix of the prepared glass. Figure 10b is TEM micrograph of the sample $70 \mathrm{TeO}_{2}-10 \mathrm{Bi}_{2} \mathrm{O}_{3}-20 \mathrm{ZnO}$ heated $400{ }^{\circ} \mathrm{C}$ for $0.5 \mathrm{~h}$, which reveals crystalline phase, droplet-free halos and amorphous glassy regions in the microstructure. When $\mathrm{Bi}_{2} \mathrm{O}_{3}$ is added in tellurite glasses, it contributes the following effects: (i) incorporation of holes and defects between two chains, (ii) formation of strong $\mathrm{Te}-\mathrm{O}-\mathrm{M}$ ion covalent bonds, and (iii) strong influence on the $\mathrm{Te}-\mathrm{axOeq}-\mathrm{Te}$ angle between two polyhedra and distorted in $\mathrm{TeO}_{3 \pm 1}$ unit followed by a 

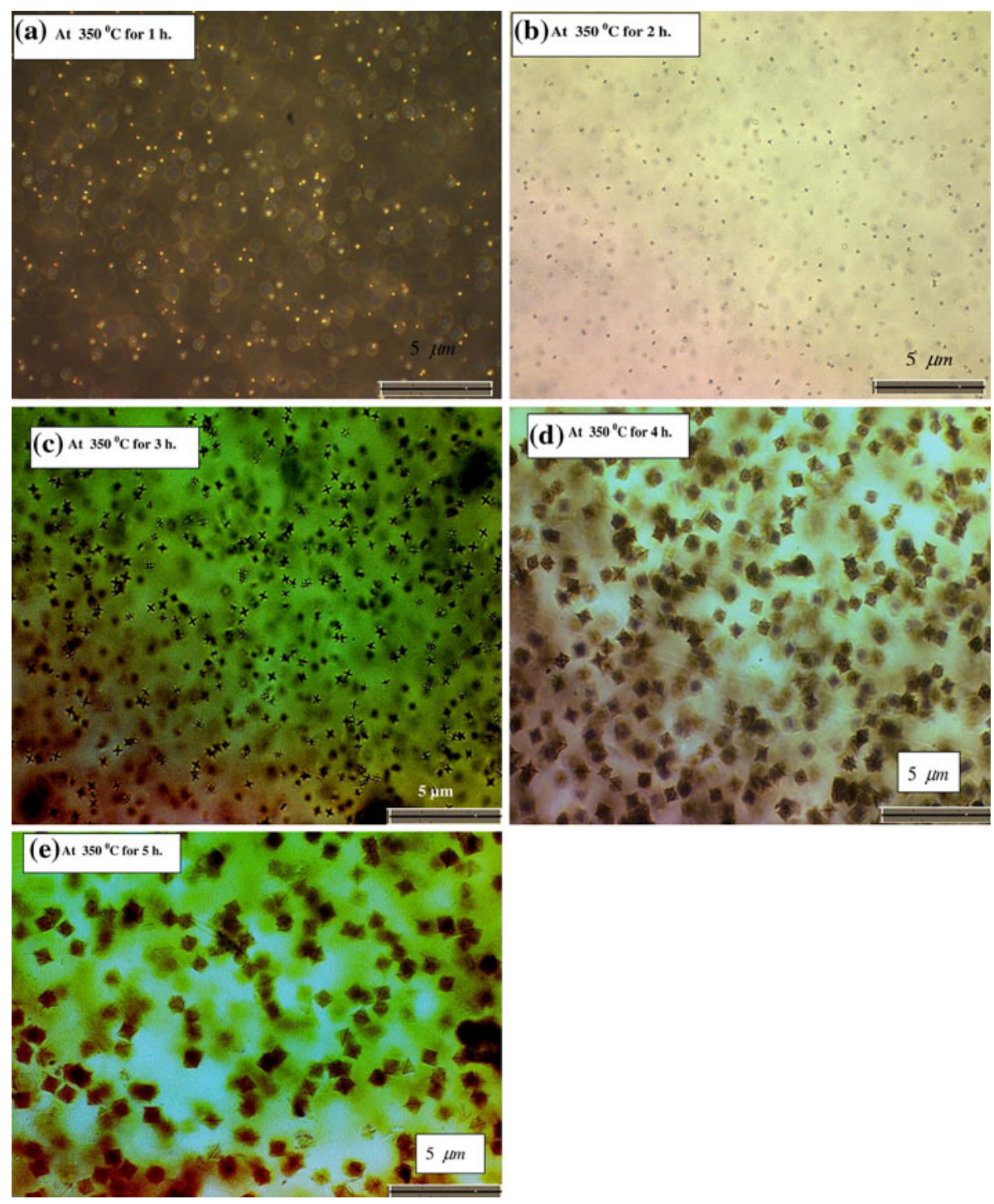

Fig. 9 Polarized optical micrographs of sample $70 \mathrm{TeO}_{2}-10 \mathrm{Bi}_{2} \mathrm{O}_{3}-20 \mathrm{ZnO}$ : a $350{ }^{\circ} \mathrm{C} / 1 \mathrm{~h}$, b $350{ }^{\circ} \mathrm{C} / 2 \mathrm{~h}$, c $350{ }^{\circ} \mathrm{C} / 3 \mathrm{~h}$, d $350{ }^{\circ} \mathrm{C} / 4 \mathrm{~h}$, e $350{ }^{\circ} \mathrm{C} / 5 \mathrm{~h}$

creation of regular $\mathrm{TeO}_{3}$ trigonal pyramid units leaving nonbridging oxygen atoms and due to the formation of $\mathrm{Te}-\mathrm{O}-\mathrm{Bi}$ kingies in the glass matrix [22-25]. So, we are suggest that when addition of $\mathrm{Bi}_{2} \mathrm{O}_{3}$ to the $\mathrm{TeO}_{2}-\mathrm{ZnO}$ glasses causes splitting of $\mathrm{O}-\mathrm{Te}-\mathrm{O}$ and $\mathrm{Zn}-\mathrm{O}-\mathrm{Zn}$ bonds and hence, the bridging oxygens (BO) are converted into non-bridging oxygens (NBO) and the electronic shell of $\mathrm{O}^{2-}$ ion is affected by polarizing action of modifying ions, since $\mathrm{Bi}^{3+}$ ions are highly polarizing with $\mathrm{Te}^{4+}$. This is due to droplet holes formed in the glass-ceramic matrix of present sample.

At temperature $375{ }^{\circ} \mathrm{C}$ for $3 \mathrm{~h}$, the matrix of glass has high dense needle shaped crystal is shown in Fig. 10c. Finally, we found that, $\mathrm{Bi}^{3+}$ played an important role to get crystallization in the tellurite glass-ceramic by using mapping TEM of glassy ceramic matrix of $70 \mathrm{TeO}_{2}-10 \mathrm{Bi}_{2} \mathrm{O}_{3}-20 \mathrm{ZnO}$.

\section{Conclusion}

From the present study of $\mathrm{TeO}_{2} / \mathrm{Bi}_{2} \mathrm{O}_{3} / \mathrm{ZnO}$ glasses, it is observed that the glass transition increase with increasing $\mathrm{ZnO}$ and $\mathrm{Bi}_{2} \mathrm{O}_{3}$ content. A highly transparent glassceramics can be successfully obtained by controlling the heat treatment precisely. The phase separation and crystallization kinetics in $70 \mathrm{TeO}_{2}-10 \mathrm{Bi}_{2} \mathrm{O}_{3}-20 \mathrm{ZnO}$ were investigated. It was found that the phase separation in the present glass occurs at $400{ }^{\circ} \mathrm{C} / 0.5 \mathrm{~h}$. The activation energies of crystallization were calculated to be 305.8 and $197 \mathrm{~kJ} \mathrm{~mol}^{-1}$ for first and second crystallization exotherms, respectively. Moreover, synthesized crystalline phases $\mathrm{Bi}_{3.2} \mathrm{Te}_{0.8} \mathrm{O}_{6.4}, \mathrm{Bi}_{2} \mathrm{Te}_{4} \mathrm{O}_{11}, \mathrm{Zn}_{2} \mathrm{Te}_{3} \mathrm{O}_{8}$, respectively, were investigated. 


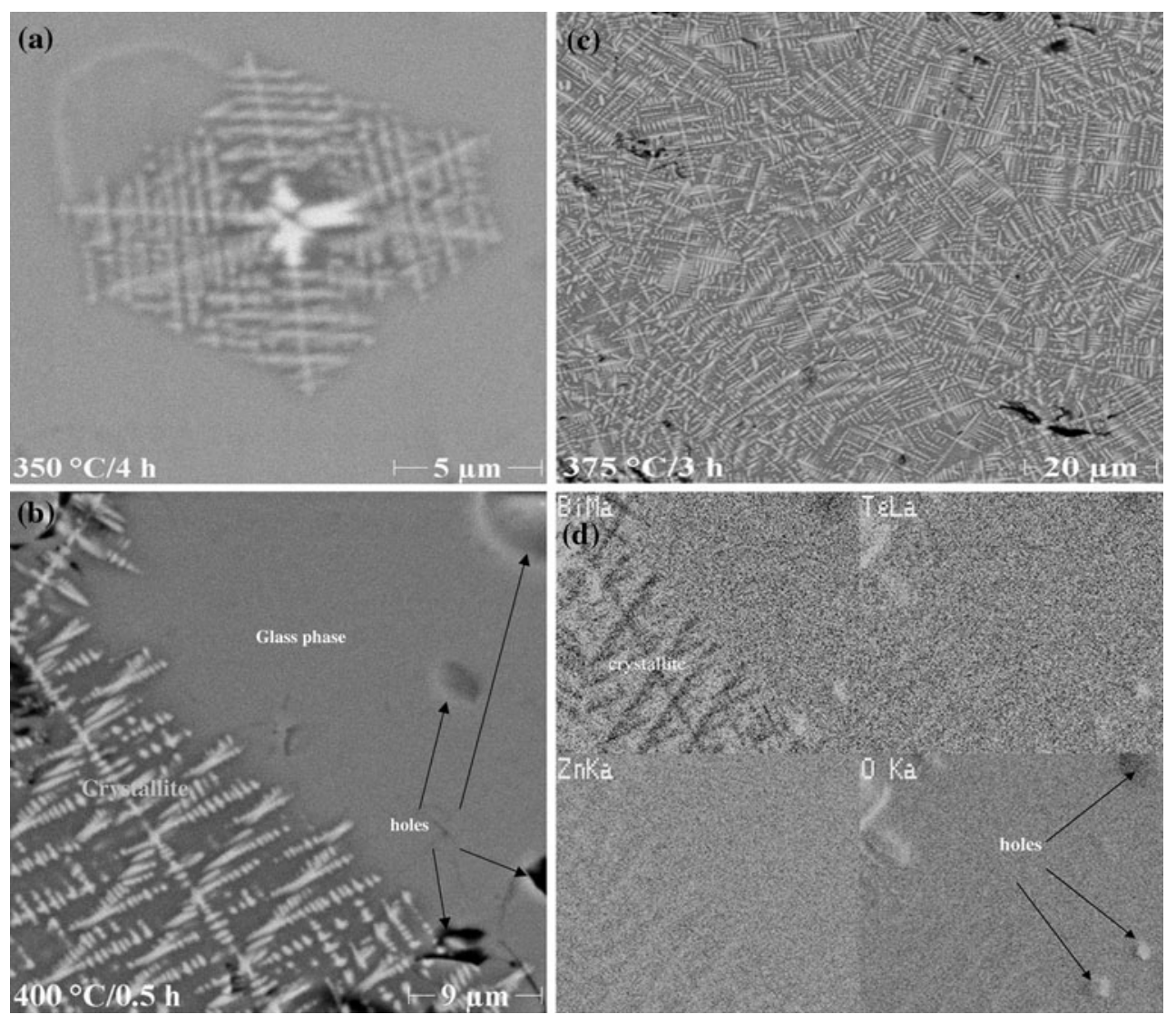

Fig. 10 TEM microphotograph of sample $70 \mathrm{TeO}_{2}-10 \mathrm{Bi}_{2} \mathrm{O}_{3}-20 \mathrm{ZnO}$ : a $350{ }^{\circ} \mathrm{C} / 4 \mathrm{~h}$, b $400{ }^{\circ} \mathrm{C} / 0.5 \mathrm{~h}$, c $375{ }^{\circ} \mathrm{C} / 3 \mathrm{~h}$, and d Mapping analysis of glass-ceramics for this sample

Acknowledgements E. Yousef wishes to thank Professor C. Russel Otto Schott Institute, Friedrich Schiller University Jena Germany for interest in this work and helpful.

Open Access This article is distributed under the terms of the Creative Commons Attribution Noncommercial License which permits any noncommercial use, distribution, and reproduction in any medium, provided the original author(s) and source are credited.

\section{References}

1. El-Mallawany R (2002) Tellurite glasses handbook: physical properties and data. CRC Press, Boca Raton

2. Lenher V, Wolesensky E (1913) J Am Chem Soc 35:718

3. Stanworth J (1952) J Soc Glass Technol 36:217

4. Sigaev VN, Sarkisov PD, Kupriyanova MV, Spiridonov YA, Lopatina EV, Stefanovich SY, Molev VI, Pernice P, Aronne A (2001) Glass Phys Chem 27:497

5. Hoppe U, Yousef E, Russel C, Neuefeind J, Hannon AC (2004) J Phys Condens Matter 16:1654

6. Sigaev VN, Pernice P, Aronne A, Akimova OV, Stefanovich SY, Scaglione A (2001) J Non-Cryst Solids 292:59

7. Kim HG, Komatsu T, Sato R, Matusita K (1993) J Non-Cryst Solids 162:201

8. Kazuhide S, Komatsu T, Kim HG, Sato R, Matusita K (1995) J Non-Cryst Solids 189:16
9. Komatsu T, Shioya K (1997) J Non-Cryst Solids 209:305

10. Tromel M, Munch E (1985) J Less-Common Met 110:421

11. Sato R, Benino Y, Fujiwara T, Komatsu T (2001) J Non-Cryst Solids 289:228

12. Senthil Murugan G, Fargin E, Rodriguez V, Adamietz F, Couzi M, Buffeteau T, Le Coustumer P (2004) J Non-Cryst Solids 344:158

13. Johnson WA, Mehl RF (1939) Trans AIME 135:419

14. Avrami M (1939) J Chem Phys 7:1103

15. Khan SA, Zulfequar M, Husain M (2002) J Phys Chem Solids 123:463

16. Goel MA, Shaaban ER, Melo FCL, Ribeiro MJ, Ferreiraa JMF (2007) J Non-Cryst Solids 353:2383

17. Kissinger HE (1957) Anal Chem 29:1702

18. Shaaban ER, Ishu Kansal M, Shapaan JM, Ferreira F (2009) J Thermal Anal Calorim 98:354

19. Shaaban ER, Dessouky MT, Abousehly AM (2008) J Philos Mag 88(7): 1099

20. Kozhukharov V, Burger H, Neov S (1986) J Polyhedron 5(3): 771

21. Popple L, Zsuzsanna S (2003) J Thermal Anal Calorim 74:375

22. Neov S, Kozhukharov V, Gerasimove I, Krezhov K, Sidzhimov B (1979) J Phys Solid State 12:2475

23. Rajendran V, Palanicelv N, Chaudhuri BK, Goswami K (2003) J Non-Cryst Solids 320:195

24. Reddy RR, Nazeer Ahmmed Y, Abdul Azeem P, Rama K (2001) J Non-Cryst Solids 286:169

25. Hanke K (1967) Naturwissenschaften 54:199 